\title{
Biodiversity of Endorhizospheric Plant Growth Promoting Bacteria
}

\author{
Jhala YK*, Shelat HN, Vyas RV and Panpatte DG \\ Department of Agricultural Microbiology, B. A. College of Agriculture, Anand Agricultural University, Anand 388 110, Gujarat, India \\ *Corresponding author: Jhala YK, Research Associate, Department of Agricultural Microbiology, B. A. College of Agriculture, Anand Agricultural University, Anand 388 \\ 110, Gujarat, India, Tel: 9925226944; E-mail: yogeshvari.jhala@gmail.com
}

Received date: Oct 28, 2014, Accepted date: Nov 19, 2014, Publication date: Nov 27, 2014

Copyright: (c) 2014 Jhala YK, et al. This is an open-access article distributed under the terms of the Creative Commons Attribution License, which permits unrestricted use, distribution, and reproduction in any medium, provided the original author and source are credited.

\begin{abstract}
Endorhizospheric bacteria also known as endophytic bacteria that resides within living plant tissues without substantially harming plants have found a large number of applications in today's agriculture such as nutrient cycling, tolerance to biotic and abiotic stress as well as promotion of plant growth. In present study an attempt has been made to test biodiversity of endophytic plant growth promoting bacteria from different plant species. As nitrogen fixation is one of the prime mechanism of plant growth promoting activity exerted by microorganisms, endophytic nitrogen fixing bacteria were isolated from from surface sterilized plant parts viz. root, stem and leaves of species Cynodon dactylon (Durva), Pothos scandens (Money plant), Ipomea batata (Sweet potato), Saccharum officinarum (Sugarcane) cv. CO.LK-8001 and CO.-84135, Musa paradica (Banana) and Zea mays (maize) cv. GM-6 by using nitrogen free media selective for growth of nitrogen fixing bacteria. In all total 10 isolates were obtained form different plant species and parts and showed variation in their biochemical and physiological characteristics. All the isolates were found to fix nitrogen and nitrogen fixation rates of all the isolates ranged from 4.0 to $36.3 \mathrm{mg} \mathrm{N}$ fixed / gm of sugar consumed. Moreover, they also showed solubilizing tri calcium phosphate in Pikovskaya's broth.
\end{abstract}

\section{Keywords: Endorhizospheric; Endophytic; Biochemical;} Physiological; Pikovskaya

\section{Introduction}

It is well known that a large number of microorganisms are found to be associated with plants. These plant associated microorganisms are the agents for stimulation of plant growth and management of plant and soil health. They colonize roots and rhizosphere i.e. the soil surface closely adhered to the plant roots. Microorganisms on the roots and in the rhizosphere get benefits from root exudates. Some of the microorganisms are capable of entering plant as endophytes that do not cause harm and can ascertain a mutualistic association [1]. Kado defined endophytic bacteria that reside within plant tissue without doing substantial harm or gaining benefit other than securing residency. Plant constitutes vast and diverse niches for endophytic organisms. The associations of endophytic microorganisms with their host are varied. Plant endophyte go far beyond well studied root nodules and exists in seeds, ovules, roots, stems, leaves and vascular tissues of plant $[2,3]$. In general, the highest endophytic densities are observed in the roots and decrease from the stem to leaves [4]. This is in consistent with the fact that endophytic bacteria can also exists in the rhizosphere and their preferred path of entering plant is via root. Endophytic bacteria that provide a beneficial effect to their host plant generally may be organized into two different systems: either they are forming symbiotic relationship through construction of specialized structure such as nodules where nitrogen fixation occurs or they may be free living in plant's vascular system. The latter is very similar to plant growth promoting rhizospheric bacteria (PGPR) [5] and many endophytic bacteria were reported to be common soil bacteria [6], therefore it is not surprising that the mechanism used by endophytic bacteria and plant growth promoting rhizospheric bacteria (PGPR) to beneficially affect their host plant seems to be similar [7]. Plant endophytes have been studied since 1940's [8]. Rosenblueth and
Martinez [9] described several endophytic bacteria from different plant species mainly belonging to genera Rhizobium, Azorhizobium, Bradyrhizobium, Methylobacterium, Burkholderia, Azospirillum, Herbaspirillum, Klebsiella, Bacillus, Pseudomonas and Gluconacetobacter. Study of biodiversity of agriculturally beneficial endophytic bacteria from different plant species provides a valuable tool for development of new tool for sustaible agriculture as the endophytic bacteria presents several advantages over rhizospheric bacteria as 1) the internal colonization strategy of endophytic bacteria provide additional benefits - the internal plant tissue provides a more uniform and protective environment for the bacteria than in the rhizosphere. 2) excessive irrigation or rainfall will not wash out endophytic bacteria as is the case for rhizosphere colonizers 3) the supply of nutrients inside the plant tissue is consistent and homogenous thus reducing stresses associated with bacterial nutrient requirement. 4) less exposed to UV radiation than the leaf surface. 5) high levels of rhizosphere competence trait not required. 6) in case of rhizobacteria inconsistent water and nutrient supply, inter and intraspecific competition can limit their performance in field.

So, present study was undertaken with the aim to study biodiversity of endophytic bacteria and study of their biochemistry and physiology in addition to evaluate their Plant growth promoting activity.

\section{Materials and Methods}

In present study, isolation of endophytic bacteria was attempted from various plant parts (root, stem and leaves) of species viz. Cynodon dactylon (Durva), Pothos scandens (Money plant), Ipomea batata (Sweet potato), Saccharum officinarum (Sugarcane) cv. CO.-84135 and Zea mays (maize) cv. GM-6 grown at Anand Agricultural University. For isolation, enrichment culture technique was employed. After collection, the plant was thoroughly washed with tap water and cut in to small pieces of $0.5 \mathrm{~cm}$ size and surface sterilized by treatment of $1 \% \mathrm{HgCl}_{2}$ (Mercuric chloride) solution 3 times for 
time interval of 30 seconds followed by treatment of $70 \%$ ethyl alcohol and finally washing with sterile distilled water. These surface sterilized pieces were then slightly burned in the low flame of burner to alleviate any surface adhering microorganism and then inoculated in to sterilized $\mathrm{N}$ free medium, under aseptic conditions and incubated at 28 $\pm 2^{\circ} \mathrm{C}$ for one week on shaker to ensure good growth of organisms. After giving two successive transfers in same selective medium, single colonies were picked from these plates to subculture by re-streaking onto $\mathrm{n}$ free media and used for further study.

\section{Physiological characterization of isolates}

Physiological properties of isolates viz. $\mathrm{NaCl}$ tolerance, $\mathrm{pH}$ tolerance and antibiotic sensitivity were checked. Here the $\mathrm{N}$ free medium supplemented with different concentration of $\mathrm{NaCl}$ (1\%-9\%) were inoculated with of test bacterial cultures and incubated at $28 \pm$ $2^{\circ} \mathrm{C}$ for 1-3 days for checking $\mathrm{NaCl}$ tolerance of isolates. One uninoculated tube of $\mathrm{N}$ free medium was kept as control. Similarly for $\mathrm{pH}$ tolerance $\mathrm{N}$ free liquid medium were prepared; $\mathrm{pH}$ was adjusted to 2.0, 3.0, 4.0, 5.0 and 6.0 by using $0.1 \mathrm{~N} \mathrm{HCl}$ and 8.0 and 9.0 with the help of $1 \mathrm{~N} \mathrm{NaOH}$. These different ranges of $\mathrm{pH}$ culture tubes were inoculated with previously grown culture of all isolates keeping uninoculated tube as control for each range of $\mathrm{pH}$ and incubated at 28 $\pm 2^{\circ} \mathrm{C}$ for $1-3$ days. Resistance to antibiotics was tested on $\mathrm{N}$ free agar using the following discs of antibiotics ( $\mu \mathrm{g} / \mathrm{disc}$ ) (Himedia Manufactured).

\begin{tabular}{|l|l|l|l|l|l|}
\hline $\begin{array}{l}\text { Sr. } \\
\text { no. }\end{array}$ & $\begin{array}{l}\text { Name of } \\
\text { antibiotic }\end{array}$ & $\begin{array}{l}\text { Concentratio } \\
\mathbf{n}(\boldsymbol{\mu g} / \mathbf{d i s c})\end{array}$ & $\begin{array}{l}\text { Sr. } \\
\mathbf{n o} .\end{array}$ & $\begin{array}{l}\text { Name of } \\
\text { antibiotic }\end{array}$ & $\begin{array}{l}\text { Concentrati } \\
\text { on }(\boldsymbol{\mu g} / \mathbf{d i s c})\end{array}$ \\
\hline 1. & Kanamycin & 30 & 6. & Tetracycline & 10 \\
\hline 2. & Rifampicin & 5 & 7. & Streptomycin & 100 \\
\hline 3. & $\begin{array}{l}\text { Chloramphenico } \\
\text { I }\end{array}$ & 10 & 8. & Ampicillin & 10 \\
\hline 4. & Gentamicin & 10 & 9. & Spectinomycin & 100 \\
\hline 5. & Carbenicillin & 100 & 10. & Polymyxin-B & 100 \\
\hline
\end{tabular}

Here, $0.05 \mathrm{ml}$ of starter cultures of all isolates was spreaded on $\mathrm{N}$ free agar plates. The discs of antibiotics were kept on inoculated plates at equidistance from each other. The plates were incubated at $28 \pm 2^{\circ} \mathrm{C}$ for $48 \mathrm{hrs}$. Sterile blank filter paper disc was used as negative control. The zone of inhibition was observed for each disc and diameter from two sides was measured. Based on radii of zone of inhibition, the isolates were classified into four types; highly resistant, $<5 \mathrm{~mm}$; resistant, $5-10 \mathrm{~mm}$; susceptible, $11-20 \mathrm{~mm}$; and highly susceptible, $>$ $20 \mathrm{~mm}[10]$.

\section{Biochemical characterization of endophytic bacterial isolates}

Microorganisms are extremely specific in their biochemical characteristics which provides tool for selective identification of the organism. Capacity of endophytic bacterial isolates to ferment sugar viz. glucose, ribose, mannitol, lactose, inositol, maltose, arabinose, raffinose, galactose, cellobiose, fructose, xylose and sucrose was tested. In addition to carbohydrate utilization test, methyl red test, Indole production, H2S production and capacity to produce amylase, gelatinase, urease and catalase was tested following standard methodology.

\section{In vitro nitrogen fixing efficiency of endophytic bacterial isolates in flask cultures}

All isolates were tested for their nitrogen fixing capacity in culture media. Most of the plant growth promoting effects shown by endophytic diazotrophs is directly correlated with its capacity to fix atmospheric nitrogen in the forms available to plants. Here, in this study the endophytic bacterial isolates were inoculated in to the selective broth medium without any nitrogen source and containing sucrose as carbon source. Inoculated media were incubated at $28 \pm 2^{\circ} \mathrm{C}$ for one week and nitrogen fixation rates were measured by MicroKjeldahl method [11] and sugar utilization was estimated by Fehling's method. The rate of nitrogen fixation was expressed as mg nitrogen fixed / gram of sucrose consumed.

\section{In vitro phosphate solubilization efficiency of isolates (PSM activity on PKVK plates)}

All isolates were tested for their phosphate solubilizing capacity in Pikovskaya's Medium. Here, Pikovskaya's broth containing tri calcium phosphate as phosphorous source was inoculated with $100 \mu \mathrm{l}$ bacterial culture and soluble phosphate content was estimated as per the method given by APHA, [12] at 3 and 5 days after inoculation.

\section{Results and Discussion}

Isolation of microorganisms, screening for desirable characters and selection of efficient strains are important steps to optimize high crop yields and improve the sustainability of the ecosystem. The present investigation was aimed to test biodiversity of plant growth promoting endophytic bacteria from different plant parts and species

\section{Source of organisms}

In all, total 24 strains were isolated from different plant parts and species. Out of these, total 10 isolates were selected on the basis of their appearance and vigor to grow on $\mathrm{N}$ free medium (Table 1).

\begin{tabular}{|l|l|l|l|}
\hline \multirow{2}{*}{$\begin{array}{l}\text { Name } \text { isolate } \\
\text { A-1 }\end{array}$} & Source of organism & Common name & Plant part \\
\cline { 2 - 4 } & Scientific name & Money plant & Leaf \\
\hline A-2 & Cynodon dactylon & Durva & Leaf \\
\hline A-3 & Ipomea batata & Sweet potato & Root \\
\hline A-4 & $\begin{array}{l}\text { Saccharum officinarum cv. } \\
\text { CO.-84135 Sugarcane }\end{array}$ & Stem \\
\hline A-5 & Zea mays cv. GM-6 & Maize & Stem \\
\hline A-6 & Pothos scandens & Money plant & Leaf \\
\hline A-7 & Cynodon dactylon & Durva & Leaf \\
\hline A-8 & Musa paradica & Banana & Root \\
\hline A-9 & $\begin{array}{l}\text { Saccharum officinarum } \\
\text { CO.LK-8001 }\end{array}$ & Sugarcane & Root \\
\hline A-10 & Zea mays cv.GM-6 & Maize & Stem \\
\hline
\end{tabular}

Table 1: Endophytic bacterial isolates of different plant parts and species. 
Page 3 of 6

\section{Isolation of endophytic bacteria}

Plant is the preliminary source of nutrition for microorganisms in soil which provides them nutrients indirectly from root exudates or dead tissues, or directly when microorganisms colonize the interior of plant roots or other organs of plant. The aim of present study is to isolate endophytic bacteria from different plant parts and species. Endophytic bacteria are generally found in the range of 103-106 gm-1 fresh weight [13]. So, it is necessary to enrich the endophytic bacteria in artificial medium to obtain the dense cultures of bacteria from plant.

In this study, after 2-3 days of the inoculation due to limitation of nutrients inside plant part, microorganisms oozes outside the plant part and grow luxariuosly in $\mathrm{N}$ free medium (Figure 1).

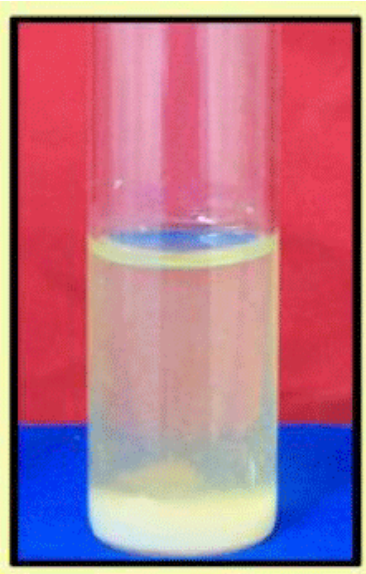

Sweet potato root

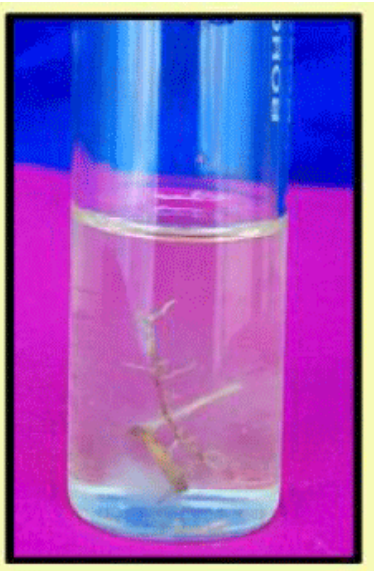

Sugarcane root
Figure 1: Oozing of endophytic bacteria from different plant parts.

These results are substantiated by reports of Cavalcante and Dobereiner and Thangaraju et al. $[14,15]$.

\section{Biochemical characterization of isolates}

Results of carbohydrate utilization pattern of all isolates are presented in Table 2 Isolates A-1 to A- 4 can utilize almost all the tested sugars viz. D-glucose, ribose, mannitol, lactose, sucrose, inositol, maltose, arabinose, raffinose, galactose, cellobiose, fructose and xylose, whereas A-5 can't utilize ribose, inositol, arabinose, xylose whereas isolates A-10 can utilize all the tested sugars, whereas isolate A-6 cannot utilize inositol and xylose, isolate A-7, A-8 and A-9 were unable to utilize rafinose, inositol, arabinose and xylose. These results confirms that all the isolates were distinct from each other.

\begin{tabular}{|l|l|l|l|l|l|l|l|l|l|l|l|l|l|}
\hline Isolate & $\mathbf{G}$ & $\mathbf{R}$ & $\mathbf{M}$ & $\mathbf{L}$ & $\mathbf{I}$ & $\mathbf{M a}$ & $\mathbf{A}$ & $\mathbf{R}$ & $\mathbf{G a}$ & $\mathbf{C}$ & $\mathbf{F}$ & $\mathbf{X}$ & $\mathbf{S}$ \\
\hline A-1 & $\perp$ & $\perp$ & $\perp$ & $\oplus$ & $\perp$ & $\perp$ & $\perp$ & $\perp$ & $\perp$ & $\perp$ & $\perp$ & $\perp$ & $\perp$ \\
\hline A-2 & $\perp$ & $\perp$ & $\perp$ & $\perp$ & $\perp$ & $\perp$ & $\perp$ & $\perp$ & $\perp$ & $\perp$ & $\perp$ & $\perp$ & $\perp$ \\
\hline A-3 & $\perp$ & $\perp$ & $\oplus$ & $\perp$ & $\perp$ & $\oplus$ & $\perp$ & $\perp$ & $\perp$ & $\perp$ & $\perp$ & $\perp$ & $\perp$ \\
\hline A-4 & $\oplus$ & $\perp$ & $\perp$ & $\perp$ & $\oplus$ & $\perp$ & $\perp$ & $\perp$ & $\perp$ & $\perp$ & $\perp$ & $\perp$ & $\perp$ \\
\hline A-5 & $\perp$ & - & $\perp$ & $\perp$ & - & $\perp$ & - & $\perp$ & $\perp$ & $\perp$ & $\perp$ & - & $\perp$ \\
\hline A-6 & $\perp$ & $\perp$ & $\perp$ & $\perp$ & - & $\perp$ & $\perp$ & $\perp$ & $\perp$ & $\perp$ & $\perp$ & - & $\perp$ \\
\hline A-7 & $\perp$ & - & $\perp$ & $\oplus$ & - & $\perp$ & - & $\perp$ & $\perp$ & $\perp$ & $\perp$ & - & $\perp$ \\
\hline A-8 & $\perp$ & - & $\perp$ & $\perp$ & - & $\perp$ & - & $\perp$ & $\perp$ & $\perp$ & $\perp$ & - & $\perp$ \\
\hline A-9 & $\perp$ & - & $\perp$ & $\perp$ & - & $\perp$ & - & $\perp$ & $\perp$ & $\perp$ & $\oplus$ & - & $\oplus$ \\
\hline A-10 & $\oplus$ & $\perp$ & $\perp$ & $\perp$ & $\oplus$ & $\perp$ & $\perp$ & $\perp$ & $\perp$ & $\perp$ & $\perp$ & $\perp$ & $\perp$ \\
\hline
\end{tabular}

Table 2: Sugar utilization by isolates after 48 hours of inoculation. Keys: $\perp$ - only acid production, $\oplus$ - acid + gas production, - - sugar not utilized, G- glucose, R - ribose, M-mannitol, L-lactose, I - inositol, Ma-maltose, A- arabinose, R-raffinose, Ga -galactose, C-cellobiose, Ffructose, $\mathrm{X}$-xylose, $\mathrm{S}$-sucrose.

The results of tests for specific breakdown products are presented in Table 3. The data revealed that all the isolates were gelatinase +ve, catalase +ve, H2S Production -ve, MR Test +ve, isolates A-3, A-4 and A-5 were showing urease -ve and all other isolates were positive for urea utilization. Indole production test was found -ve for isolates A-1 to A-5, whereas isolates A-6 to A-10 were found to be indole producers. All the isolates were showing starch utilization test negative.

\begin{tabular}{|c|c|c|c|c|c|c|c|}
\hline \multirow[t]{2}{*}{ Isolates } & Gelatinase & Methyl red & Urease & Catalase & $\begin{array}{l}\text { Indole } \\
\text { production }\end{array}$ & $\begin{array}{l}\text { Starch } \\
\text { utilization }\end{array}$ & \multirow{2}{*}{$\begin{array}{l}\mathrm{H} 2 \mathrm{~S} \\
\text { production } \\
\text { After } 120 \mathrm{hrs} .\end{array}$} \\
\hline & \multicolumn{6}{|l|}{ After 48 hrs. } & \\
\hline A-1 & + & + & + & + & - & - & - \\
\hline A-2 & + & + & + & + & - & - & - \\
\hline A-3 & + & + & - & + & - & - & - \\
\hline A-4 & + & + & - & + & - & - & - \\
\hline A-5 & + & + & - & + & - & - & - \\
\hline A-6 & + & + & + & + & + & - & - \\
\hline
\end{tabular}




\begin{tabular}{|c|c|c|c|c|c|c|c|}
\hline A-7 & + & + & + & + & + & - & - \\
\hline$A-8$ & + & + & + & + & + & - & - \\
\hline A-9 & + & + & + & + & + & - & - \\
\hline$A-10$ & + & + & + & + & + & - & - \\
\hline
\end{tabular}

Table 3: Tests for specific breakdown products of isolates.

These results are supported by Muthukumarasamy et al., [16] who had reviewed that endophytic bacteria (Gluconacetobacter diazotrophicus) was oxidase -ve, catalase +ve and can utilize $\mathrm{D}$ galactose, D-xylose, D-raffinose, D-arabinose, melibiose, maltose, sorbitol, D-mannitol as carbon source in addition to sucrose. From overall biochemical characterizarion studies it was ascertain that isolate A-1 to A-5 may belong to genus Acetobacter and Isolate A- 6 to A-10 to Azospirillum as per Bergey's manual of all the biochemical tests for characterization of endophytic bacterial isolates have well established similarities of isolates A-1 to A-5 with genus Acetobacter whereas characteristics of isolates A- 6 to A-10 were similar to that of genus Azospirillum so we can classify them according to Bergey's manual of systematic bacteriology (1983) as Acetobacter and Azospirillum species.

\section{Physiological characterization}

$\mathrm{pH}$ tolerance of isolates: Physiological tests were carried out to find optimum $\mathrm{pH}$ range, salinity tolerance and to determine antibiotic resistance capacity of isolates. The results of $\mathrm{pH}$ tolerance are presented in Table 4. Good growth of isolates A-3 and A-5 and was observed in $\mathrm{pH}$ range of 3-6. Isolates A-1 and A-4 were observed to grow in the $\mathrm{pH}$ range of 2-8 but optimum growth occurred between 3-7 $\mathrm{pH}$ and $\mathrm{A}-2$ was observed to grow between $2-8 \mathrm{pH}$ and optimum growth was observed in the range of 2-6. Best growth of isolates A-9 and A-10 occurred at $\mathrm{pH} 4-8$, whereas isolates A-7, A-8 can grow at pH 3-8.

\begin{tabular}{|l|l|l|l|l|l|l|l|l|}
\hline \multirow{2}{*}{ Isolates } & \multicolumn{6}{|l}{ pH range tested } \\
\cline { 2 - 10 } & 2 & 3 & 4 & 5 & 6 & 7 & 8 & 9 \\
\hline A-1 & + & ++ & ++ & ++ & ++ & ++ & + & - \\
\hline A-2 & ++ & ++ & ++ & ++ & ++ & + & - & - \\
\hline A-3 & + & ++ & ++ & ++ & ++ & + & + & - \\
\hline A-4 & + & ++ & ++ & ++ & ++ & ++ & + & - \\
\hline A-5 & + & ++ & ++ & ++ & ++ & + & + & - \\
\hline A-6 & - & - & - & ++ & ++ & ++ & ++ & - \\
\hline A-7 & - & + & ++ & ++ & ++ & ++ & + & - \\
\hline A-8 & - & + & + & ++ & ++ & ++ & ++ & - \\
\hline A-9 & - & - & ++ & ++ & ++ & ++ & ++ & - \\
\hline A-10 & - & - & ++ & ++ & ++ & ++ & ++ & + \\
\hline
\end{tabular}

Table 4: $\mathrm{pH}$ tolerance of isolates. + Moderate growth, ++ Good growth, - No growth.
All the isolates were not found tolerate $9 \mathrm{pH}$ except A-10. These results are in agreement with findings of Stephan et al. [17] who reported optimum range of 3-7 for growth of endophytic isolate of sugarcane.

\section{Salinity tolerance}

The results of salt tolerance are presented in Table 5. Best growth of all the isolates except A-1 was observed up to $6 \% \mathrm{NaCl}$ concentration, whereas they can grow poorly up to $8 \% \mathrm{NaCl}$ concentration. A-1 can tolerate $\mathrm{NaCl}$ concentration up to $4 \%$. Ahmad et al. [18] reported endophytic bacteria can tolerate $\mathrm{NaCl}$ concentration up to $1.5 \%$.

\begin{tabular}{|l|l|l|l|l|l|l|l|l|l|l|}
\hline Isolates & $1 \%$ & $2 \%$ & $3 \%$ & $4 \%$ & $5 \%$ & $6 \%$ & $7 \%$ & $8 \%$ & $9 \%$ & $10 \%$ \\
\hline A-1 & ++ & ++ & ++ & ++ & - & - & - & - & - & - \\
\hline A-2 & ++ & ++ & ++ & ++ & ++ & ++ & + & + & + & - \\
\hline A-3 & ++ & ++ & ++ & ++ & ++ & ++ & + & + & + & - \\
\hline A-4 & ++ & ++ & ++ & ++ & ++ & ++ & + & + & + & - \\
\hline A-5 & ++ & ++ & ++ & ++ & ++ & ++ & + & + & + & - \\
\hline A-6 & ++ & ++ & ++ & ++ & ++ & ++ & + & + & + & - \\
\hline A-7 & ++ & ++ & ++ & ++ & ++ & ++ & + & + & + & - \\
\hline A-8 & ++ & ++ & ++ & ++ & ++ & ++ & + & + & + & - \\
\hline A-9 & ++ & ++ & ++ & ++ & ++ & ++ & + & + & + & - \\
\hline A-10 & ++ & ++ & ++ & ++ & ++ & ++ & + & + & + & - \\
\hline
\end{tabular}

Table 5: Salinity tolerance of isolates. + Moderate growth, ++ Good growth, - No growth.

\section{Intrinsic antibiotics resistance profile}

Various endophytic bacterial isolates showed variable response to different antibiotics tested (Table 6). Isolates A-1 to A-5 were found to be resistant to all the tested antibiotics. Whereas isolate A- 6 was found resistant to streptomycin $(100 \mu \mathrm{g} / \mathrm{disc})$, rifampicin $(5 \mu \mathrm{g} / \mathrm{disc})$, spectinomycin $(100 \mu \mathrm{g} / \mathrm{disc})$, polymyxin-B $(100 \mu \mathrm{g} / \mathrm{disc})$, tetracycline $(10 \mu \mathrm{g} / \mathrm{disc})$, carbenicillin $(100 \mu \mathrm{g} / \mathrm{disc})$, chloramphenicol $(10 \mu \mathrm{g} / \mathrm{disc})$. A-7 was resistant to all antibiotics except gentamycin ( $10 \mu \mathrm{g} / \mathrm{disc})$. A-8 was resistant to streptomycin $(100 \mu \mathrm{g} / \mathrm{disc})$, spectinomycin $(100 \mu \mathrm{g} /$ disc), polymyxin-B (100 $\mu \mathrm{g} / \mathrm{disc})$, tetracycline $(10 \mu \mathrm{g} / \mathrm{disc})$, chloramphenicol $(10 \mu \mathrm{g} / \mathrm{disc})$. A-9 was resistant to all antibiotics except Tetracycline $(10 \mu \mathrm{g} / \mathrm{disc})$. A-10 can resist streptomycin $(100 \mu \mathrm{g} /$ disc), spectinomycin $(100 \mu \mathrm{g} / \mathrm{disc})$, polymyxin-B $(100 \mu \mathrm{g} / \mathrm{disc})$, chloramphenicol $(10 \mu \mathrm{g} / \mathrm{disc})$. These results are in conformity with the findings of Mehnaz and Lazarovits, (2006) who showed endophytic 
Page 5 of 6

isolates belonging to genus Azospirillum isolates resistant to ampicillin and cycloheximide up to $100 \mu \mathrm{g} / \mathrm{ml}$ and sensitive to the gentamycin, kanamycin, rifampicin, spectinomycin, streptomycin, and tetracycline at $25 \mu \mathrm{g} / \mathrm{ml}$.

Mowade and Bhattacharyya, [19] reported endophytic isolate (Acetobacter diazotrophicus) found to be resistant to ampicillin, erythromycin and roxithromycin even at higher concentrations and less sensitive to penicillin and tetracyclin. The sensitivity of the bacterium was observed more with antibiotics like ciprofoxacine, doxicycline, rifampicin and chloramphenicol.

\begin{tabular}{|c|c|c|c|c|c|c|c|c|c|c|}
\hline \multirow[b]{2}{*}{ Isolates } & \multicolumn{10}{|c|}{ Antibiotic tested } \\
\hline & $\begin{array}{l}\text { G } \\
\text { (10) }\end{array}$ & $\begin{array}{l}S \\
(100)\end{array}$ & $\begin{array}{l}R \\
(5)\end{array}$ & $\begin{array}{l}K \\
(30)\end{array}$ & $\begin{array}{l}\text { A } \\
\text { (10) }\end{array}$ & $\begin{array}{l}\text { Se } \\
(100)\end{array}$ & $\begin{array}{l}P \\
(100)\end{array}$ & $\begin{array}{l}T \\
(10)\end{array}$ & $\begin{array}{l}\mathrm{Cb} \\
(100)\end{array}$ & $\begin{array}{l}C \\
\text { (10) }\end{array}$ \\
\hline A-1 & $\mathrm{HR}$ & $\mathrm{HR}$ & $\mathrm{HR}$ & $\mathrm{HR}$ & $\mathrm{HR}$ & $\mathrm{HR}$ & $\mathrm{HR}$ & $\mathrm{HR}$ & $\mathrm{HR}$ & $\mathrm{HR}$ \\
\hline A-2 & $\mathrm{HR}$ & $\mathrm{HR}$ & $\mathrm{HR}$ & HR & $\mathrm{HR}$ & $\mathrm{HR}$ & $\mathrm{HR}$ & $\mathrm{HR}$ & $\mathrm{HR}$ & $\mathrm{HR}$ \\
\hline A-3 & $\mathrm{HR}$ & $\mathrm{HR}$ & $\mathrm{HR}$ & HR & $\mathrm{HR}$ & $\mathrm{HR}$ & $\mathrm{HR}$ & $\mathrm{HR}$ & $\mathrm{HR}$ & $\mathrm{HR}$ \\
\hline A-4 & $H R$ & $\mathrm{HR}$ & $\mathrm{HR}$ & $H R$ & $\mathrm{HR}$ & $\mathrm{HR}$ & $\mathrm{HR}$ & $\mathrm{HR}$ & $\mathrm{HR}$ & $\mathrm{HR}$ \\
\hline$A-5$ & $\mathrm{HR}$ & $\mathrm{HR}$ & $\mathrm{HR}$ & $\mathrm{HR}$ & $\mathrm{HR}$ & $\mathrm{HR}$ & $\mathrm{HR}$ & $\mathrm{HR}$ & $\mathrm{HR}$ & $\mathrm{HR}$ \\
\hline ACG-1 & $\mathrm{HR}$ & $\mathrm{HR}$ & $\mathrm{HR}$ & $\mathrm{HR}$ & $\mathrm{HR}$ & $\mathrm{HR}$ & $\mathrm{HR}$ & $\mathrm{HR}$ & $\mathrm{HR}$ & $\mathrm{HR}$ \\
\hline A-6 & $\mathrm{s}$ & $\mathrm{HR}$ & $\mathrm{R}$ & $\mathrm{s}$ & $\mathrm{s}$ & $\mathrm{HR}$ & $\mathrm{HR}$ & $\mathrm{HR}$ & $\mathrm{HR}$ & $\mathrm{HR}$ \\
\hline A-7 & $s$ & $\mathrm{R}$ & $\mathrm{R}$ & $\mathrm{R}$ & $\mathrm{HR}$ & $\mathrm{HR}$ & $\mathrm{HR}$ & $\mathrm{HR}$ & $\mathrm{HR}$ & $\mathrm{HR}$ \\
\hline A-8 & $\mathrm{s}$ & $\mathrm{R}$ & $\mathrm{s}$ & $\mathrm{s}$ & $\mathrm{s}$ & $\mathrm{HR}$ & $\mathrm{HR}$ & $\mathrm{R}$ & $s$ & $\mathrm{R}$ \\
\hline A-9 & $R$ & $\mathrm{HR}$ & $\mathrm{R}$ & $H R$ & $H R$ & $\mathrm{R}$ & $\mathrm{HR}$ & $\mathrm{s}$ & $\mathrm{R}$ & $\mathrm{HR}$ \\
\hline A-10 & $s$ & $\mathrm{R}$ & $\mathrm{s}$ & $\mathrm{s}$ & $s$ & $\mathrm{HR}$ & $\mathrm{HR}$ & $\mathrm{s}$ & $s$ & $\mathrm{HR}$ \\
\hline ASA-1 & $\mathrm{s}$ & $\mathrm{R}$ & $\mathrm{R}$ & $\mathrm{s}$ & $\mathrm{HR}$ & $\mathrm{R}$ & $\mathrm{HR}$ & $\mathrm{R}$ & $\mathrm{s}$ & $\mathrm{R}$ \\
\hline
\end{tabular}

Table 6: Intrinsic antibiotic resistance profiles of isolates Note: The figures in parentheses indicate units: G- Gentamicin; A- Ampicillin; TTetracycline; P- Polymyxin-B; C- Cloramphenicol; S- Streptomycin; K- Kanamycin;R- Rifampicin; Cb- Carbenicillin; Se- Spectinomycin.

\begin{tabular}{|l|l|}
\hline $\begin{array}{l}\text { Symbols } \\
\text { zone }(\mathbf{m m})\end{array}$ & Radius of inhibition \\
\hline R & $5-10 \mathrm{~mm}$ \\
\hline HR & $<5 \mathrm{~mm}$ \\
\hline S & $11-20 \mathrm{~mm}$ \\
\hline HS & $>20 \mathrm{~mm}$ \\
\hline
\end{tabular}

From the overall physioloical charcterization study, it should be noted that all the isolates were different from each other and regardless of isolation source, they can tolerate adverse conditions for growth and survival such as changes in $\mathrm{pH}$, high salt concentration and antibiotic production by competing microorganisms making them more efficient to survive under varied circumstances and impart benefit to plant through their plant growth promoting activities.

\section{Nitrogen fixation efficiency of isolates}

Comparison of endophytic diazotrophic bacteria with free living nitrogen fixers showed that internalized bacteria are much more likely to contribute significantly to nitrogen economy of the plant $[20,21]$. The results of in vittro nitrogen fixation efficiency are mentioned in Table 7. All the isolates were confirmed to have ability of fixing atmospheric nitrogen. It was revealed from the result that nitrogen fixing potentiality of these isolates were ranged from 4.0-36.3 mg N/g of sugar consumed and isolate A-10 was showing highest nitrogen fixation capacity among all the isolates $(36.3 \mathrm{mg} \mathrm{N} / \mathrm{g}$ of sugar consumed).

\begin{tabular}{|l|l|}
\hline Isolate & $\begin{array}{l}\mathbf{m g} \text { nitrogen/g of sugar } \\
\text { consumed }\end{array}$ \\
\hline A-1 & 20.0 \\
\hline A-2 & 8.1 \\
\hline A-3 & 23.9 \\
\hline A-4 & 29.9 \\
\hline A-5 & 24.3 \\
\hline A-6 & 23.3 \\
\hline A-7 & 4.0 \\
\hline A-8 & 21.3 \\
\hline A-9 & 20.8 \\
\hline A-10 & 36.3 \\
\hline
\end{tabular}

Table 7: In vitro nitrogen fixation capacity of isolate.

Similarly Bhowmick and Konde [22] reported N fixing potentiality of endophytic bacteria (Aceobacter diazotrophicus) ranging from $102-385 \mathrm{mg} / \mathrm{g}$ of sucrose consumed In general, this finding widened the scope to isolate more efficient strains of endophytic bacteria from different plant parts and species.

\section{In vitro phosphate solubilizing activity of isolates}

Data regarding phosphate solubilization activity of isolates are presented in Table 8. Estimation of $\mathrm{P}$ in the medium revealed that all the strains released $\mathrm{P}$ from tri calcium phosphate (TCP). Isolate A-8 recorded maximum soluble phosphate $(21.00 \mathrm{P} \mu \mathrm{g} / \mathrm{ml})$ at $3 \mathrm{DAI}$, closely followed by A-7 $(14.96 \mathrm{P} \mu \mathrm{g} / \mathrm{ml})$ and A-5 $(11.22 \mathrm{P} \mu \mathrm{g} / \mathrm{ml})$ and with isolates A-1, A- 6 and A-8 decreased after 5 DAI because of utilization of solubilized phosphate by microorganisms.

\begin{tabular}{|l|l|l|}
\hline Isolates & $\begin{array}{l}\mathbf{P} \mathbf{\mu g} / \mathbf{m l} \\
\text { 3 DAl }\end{array}$ & $\begin{array}{l}\mathbf{P} \mathbf{\mu g} / \mathbf{m l} \\
\text { 5 DAl }\end{array}$ \\
\hline A-1 & 3.22 & 2.78 \\
\hline A-2 & 11.04 & 18.96 \\
\hline A-3 & 1.89 & 7.44 \\
\hline A-4 & 1.19 & 4.44 \\
\hline A-5 & 10.22 & 12.30 \\
\hline
\end{tabular}




\begin{tabular}{|l|l|l|}
\hline A-6 & 11.22 & 6.33 \\
\hline A-7 & 14.96 & 23.81 \\
\hline A-8 & 21.00 & 20.19 \\
\hline A-9 & 2.93 & 10.04 \\
\hline A-10 & 3.89 & 11.11 \\
\hline
\end{tabular}

Table 8: In vitro phosphate solubilization efficiency of isolates.

The present findings established the phosphate solubilization as an additional benefit of endophytic bacterial isolate and thereby, apart from fixing atmospheric nitrogen all the isolates can also improve the availability of phosphorous in crop's rhizosphere.

\section{Conclusion}

Endophytic bacteria with plant growth promoting activity can overcome the limitations faced by rhizopheric bacteria. here 10 isolates were obtained from different plant species and were found to tolerate adverse environmental condition such as changes in salinity, $\mathrm{pH}$ and antibiotic secretion by competing microorganisms. Moreover all the isolates were capable of two most mportant plant nutrients viz. nitrogen and phosphorous. Study of such biodiversity can open up the direction of formulation of novel microbial inoculants for application in variety of crop species regardless of their origin.

\section{References}

1. Azovedo JL, Maccheroni W, Pereira JO de Araujo WL (2000) Endophytic microorganisms: A review on insect control and recent advances on tropical plants. Electron. J. Biotechnol 3: 40-65.

2. Lodewyckx C, Vangronsveld J, Porteous F, Moore ERB, Taghavi S, et al. (2002) Endophytic bacteria and their potential applications. Cri. Rew. in Pl. Sci. 21: 583-606.

3. Zinniel DK, Lambrecht P, Harris NB, Feng Z, Kuczmarski D, et al. (2002) Isolation and characterization of endophytic colonizing bacteria from agronomic crops and prairie plants. Appl Environ Microbiol 68: 2198-2208.

4. Lamb TG, Tonkyn DW, Kluepfel DA (1996) Movement of Pseudomonas aureofaciens from rhizosphere to aerial plant tissues. Can. J. of Micro 42: 1112-1120.

5. Di Fiori S, Gallo M (1995) Endophytic bacteria: their possible role in the host plant. In: Azospirillum VI and related microorganisms. Springer Verlag, Berlin, Heidelberg, New York: 169.

6. Mc Inray JA, Kloepper JW (1994) Novel bacterial taxa inhabiting internal tissues of sweet corn and cotton. In: Improving plant productivity with rhizospheric bacteria. Australia: CSIRO: 190.

7. Hoflich G, Wiehe W, Kunn G (1994) Plant growth stimulation by inoculation with symbiotic and associative rhizosphere mechanism. Experientia 50: 897-905.

8. Tervet IW, Hollis JP (1948) Bacteria in storage organ of healthy plants. Phytopathology 38: 960-967.

9. Rosenblueth M, Martínez-Romero E (2006) Bacterial endophytes and their interactions with hosts. Mol Plant Microbe Interact 19: 827-837.

10. Abaidoo RC, Keyser HH, Singleton PW, Borthakur D (2002) Comparison of molecular and antibiotic resistance profile methods for the population analysis of Bradyrhizobium spp. (TGx) isolates that nodulate the new TGx soybean cultivars in Africa. J Appl Microbiol 92: 109-117.

11. AOAC (1965) Official methods of analysis of the association of official agricultural chemists. 10: 744-745.

12. APHA (1995) Standard methiods for the examination of water and wastewater, phosphates. Published by American Public Health Association Washington DC 2005, Asea.

13. Hallaman RM, Quadt-Hallman A, Mahatee WF, Kloepper JW (1997) Bacterial endophytes in agricultural crops. Can. J. Microbiol 43: 895-914.

14. Cavalcante VA, Dobereiner J (1988) A new acid tolerant nitrogen fixing bacterium associated with sugarcane. Plant Soil 108: 23-31.

15. Thangaraju M, Jaykumar P (2002) Acetobacter diazotrophicus: A new and potential endophytic nitrogen fixing bacterium associated with sugarcane. Biotechnology of Biofertilizers: 340-352.

16. Muthukumarasamy R, Revathi G, Seshadri S, Lakshminara SC (2002) Gluconacetobacter diazotrophicus (syn. Acetobacter diazotrophicus) a promising diazotrophic endophyte in tropics. Curr. Sci 83: 137-145.

17. Stephan MP, Oliveira M, Teixeira KRS, Martinez DG, Dobereiner J (1991) Physiology and dinitrogen fixation of Acetobacter diazotrophicus. FEMS Microbiology Letters 77: 67-72.

18. Ahmad I, Sharma J, Ahmad F (2004) Isolation and characterization of resistance traits of indigenous strains of Acetobacter diazotrophicus associated with sugarcane. Sugartech 6: 41-46.

19. Mowade S, Bhattacharyya P (2000) Resistance of P-solubilizing Acetobacter diazotrophicus to antibiotics. Cur. sci. 79: 1591-1594.

20. Quispel AA (1991) Critical evaluation of the prospects for nitrogen fixation with non legumes. Plant soil 137: 1-11.

21. Cocking EC (2003) Endophytic colonization of plant roots by nitrogen fixing bacteria. Plant soil 252: 169-175.

22. Bhowmik SN, Konde BK (1997) Isolation of efficient dinitrogen fixing Acetobacter from indigenous sugarcane genotypes. J. Maharastra Agril. Univ 22: 364-365. 